\title{
Biomarkører i spinalvæske ved demens
}

\section{Sammendrag \\ Bakgrunn. Vi ville vurdere om biomar- kører som abeta42, tau og p-tau i spi- nalvæske kan skille Alzheimers syk- dom fra andre demenssykdommer.}

Materiale og metode. Etter søk i PubMed ble studier som inkluderte minst to pasientgrupper Imed Alzheimers sykdom, demens med lewylegemer, frontotemporal demens og/eller vaskulær demens) og der sensitivitet og spesifisitet var rapportert valgt ut. Kvaliteten på artiklene ble skåret fra 0 til 7.

Resultater. 25 artikler ble inkludert. Kvalitetsskårene varierte mellom 2 og 5 . I de fleste studiene var det statistisk signifikante forskjeller i konsentrasjon for alle de tre markørene mellom Alzheimers sykdom og hver av de tre andre demenssykdommene, med unntak av abeta42 for Alzheimers sykdom versus demens med lewylegemer. Alzheimers sykdom ble skilt fra vaskulær demens med sensitivitet og spesifisitet som varierte mellom $77-87 \%$ og 62-80\% (abeta42), 79-100\% og $14-100 \%$ (tau), $78-80 \%$ og $63-96 \%$ (p-tau 181), fra demens med lewylegemer med sensitivitet og spesifisitet som varierte mellom $72-94 \%$ og 53-92\% (tau), $68-85 \%$ og $61-85 \%$ (p-tau 181) og fra frontotemporal demens med sensitivitet og spesifisitet som varierte mellom $37-91 \%$ og $59-92 \%$ (abeta 42 ), $58-88 \%$ og $68-92 \%$ (tau), $44-91 \%$ og $79-100 \%$ (p-tau181).

Fortolkning. Metodebegrensninger og varierende resultater $\mathrm{i}$ inkluderte studier vanskeliggjør tolkingen. Det er foreløpig ikke nok holdepunkter for å hevde at spinalvæskemarkører alene kan bidra til å skille Alzheimers sykdom fra andre demenstyper.

Deler av artikkelen er basert på en studentoppgave fra Universitetet i Bergen (1).

> Se også side 2218

\section{Ragnhild Eide Skogseth}

Institutt for klinisk medisin

Universitetet i Bergen

og

Medisinsk avdeling

Voss sjukehus

\section{Tormod Fladby}

Nevrologisk avdeling

Akershus universitetssykehus

og

Fakultetsdivisjonen Akershus universitetssykehus Universitetet i Oslo

\section{Ezra Mulugeta}

Stavanger universitetssjukehus

og

Wolfson Centre for Age Related Diseases King's College, London

\section{Dag Aarsland}

daarsland@gmail.com

Senter for eldremedisin

Alderspsykiatrisk seksjon

Psykiatrisk klinikk

Stavanger universitetssjukehus

og

Universitetet i Oslo/Akershus universitetssykehus

Antallet personer som får en demensdiagnose er økende. Den hyppigste årsaken til demens er Alzheimers sykdom. Demens er en klinisk diagnose, mens supplerende undersøkelser som MR eller CT og blodprøver gjennomføres for å utelukke årsaker til sekundær demens. De ulike demenssykdommene bestemmes også klinisk, men den kliniske diagnostikken har varierende nøyaktighet sammenliknet med obduksjonsdiagnoser (2). Det er derfor behov for gode biomarkører for å diagnostisere og skille de ulike demenssykdommene. Dersom sykdomsrettet behandling blir en realitet, vil presis diagnostikk tidlig i forløpet bli spesielt viktig.

En god biomarkør for Alzheimers sykdom bør reflektere sentrale nevropatologiske trekk ved tilstanden, den bør valideres mot nevropatologiske obduksjonsfunn, den bør være presis (klare å detektere Alzheimers sykdom tidlig og skille den fra andre tilstander som gir demens), den bør være reliabel, ikke-invasiv, enkel å utføre og billig, og den bør ha sensitivitet og spesifisitet over $80 \%$ (3). Spinalvæskeanalyse er mest lovende - det skiller godt mellom dem med symptomer på tidlig Alzheimers sykdom og friske eldre og er allerede til en viss grad $i$ klinisk bruk (tab 1) $(4,5)$. Det finnes relativt få studier der man har undersøkt markørenes evne til å skille de ulike demenssykdom- mene fra hverandre (6). Dette er viktig fordi de har ulik prognose og reagerer forskjellig på legemidler.

Hensikten med denne litteraturgjennomgangen var derfor å vurdere markørenes evne til å skille Alzheimers sykdom fra de andre mest prevalente demenssykdommene.

\section{Materiale og metode}

Søk ble gjort i PubMed. Nærmere beskrivelse av søkestrategi og utvelgelse av artikler finnes i den utvidede metodebeskrivelsen på nett. Sammendraget til alle treff ble lest, og vi skaffet oss fulltekstversjoner av artiklene som fylte (eller som det ikke kunne utelukkes fylte) inklusjonskriteriene:

- En eller flere av markørene abeta42, tau eller p-tau var blitt analysert i spinalvæske - Minst to pasientgrupper (av alternativene Alzheimers sykdom, frontotemporallappsdemens, demens med lewylegemer og vaskulær demens) var inkludert

- Sensitivitet og spesifisitet for markørenes evne til å skille mellom disse sykdommene ble rapportert

Dersom det var flere artikler basert på samme materiale, ble kun én av disse inkludert. Inkluderte artikler ble vurdert etter en modifisert versjon av en tidligere brukt kvalitetsskala (7). Faktorer som ble tillagt vekt var diagnostikk (klinisk eller obduksjonsverifisert), pasientseleksjon, prøvehåndtering og antall pasienter.

Poengene ble summert (maksimalskår 7) og median kvalitetsskår ble beregnet. Median, minimum og maksimum sensitivitet og spesifisitet blir presentert for hver gruppe, basert på alle artiklene der dette var rapportert. Statistisk signifikans ble satt til $5 \%$.

\section{Resultater}

I alt 25 artikler ble inkludert (fig 1).

\section{Hovedbudskap}

- Spinalvæskeanalyse skiller mellom personer med tidlig Alzheimers sykdom og friske eldre

- Spinalvæskeanalyse skiller ikke godt nok mellom Alzheimers sykdom og andre demenssykdommer

- Metodebegrensninger og varierende resultater i inkluderte studier gjør tolking vanskelig 
Totalt antall treff ved søkene, $n=208$

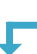

Artikler som fylte eller som det ikke kunne utelukkes fylte inklusjonskriteriene etter gjennomgang av abstrakt, $\mathrm{n}=107$

Inkluderte artikler, $\mathrm{n}=25$

Artikler som ved gjennomgang

av fulltekstversjon ikke fylte

inklusjonskriteriene, $\mathrm{n}=83$

Figur 1 Litteratursøk. Antall treff, inkluderte og ekskluderte artikler. Én artikkel ble funnet ved gjennomgang av referanselister, totalt antall inkluderte artikler ble derfor 25

Alzheimers sykdom og vaskulær demens I 13 artikler ble pasienter med Alzheimers sykdom og vaskulær demens sammenliknet og sensitivitet og spesifisitet rapportert (8-20). To studier hadde delvis overlappende pasientmateriale $(8,9)$, derfor ble kun den ene (9) inkludert. Vi sto da igjen med 12 studier med til sammen 1013 pasienter (fig 2, tab 2, e-tab 3). Median kvalitetsskår var 3,5 (spredning 2-5)

I fem studier hadde man undersøkt om det var forskjell i konsentrasjon av abeta42 hos pasienter med Alzheimers sykdom og hos pasienter med vaskulær demens, i fire ble det funnet statistisk signifikant $(\mathrm{p}<0,05)$ lavere konsentrasjon hos dem med Alzheimers sykdom (9-12). I en studie var pasientene delt inn i sannsynlig og mulig Alzheimers sykdom ut fra NINCDS-ADRDA-kriteriene (21). Det ble funnet statistisk signifikant lavere verdier i «sannsynliggruppen» enn i «muliggruppen» (13). Fra tre studier var det rapportert sensitivitet og spesifisitet til abeta42 $(9,11,14)$ (fig 2, tab 2, e-tab 3).

Det var åtte studier der man hadde sett på forskjellen i taukonsentrasjon mellom grup- pene. I seks var det statistisk signifikant høyere verdi hos dem med Alzheimers sykdom $(9,10,13-16)$, i de to andre var verdiene ikke forskjellige $(11,17)$. Sensitivitet og spesifisitet for total taukonsentrasjon ble rapportert i sju studier $(9,14-19)$ (fig 2 , tab 2, e-tab 3).

I alle de fem studiene der man hadde sett på forskjeller i p-taukonsentrasjon (p-tau 181, p-tau 199 og p-tau 231), var det statistisk signifikant høyere konsentrasjoner hos pasientene med Alzheimers sykdom enn hos dem med vaskulær demens $(9,11,12,15$, 16). Det var tre studier der sensitivitet og spesifisitet for p-tau 181 var rapportert $(9$, $16,20)$ (fig 2, tab 2, e-tab 3).

Ulike kombinasjoner av abeta42, tau og p-tau er blitt analysert i seks studier, med sensitivitet $86-97 \%$ og spesifisitet $42-100 \%$ $(9,10,12-14,19)$

\section{Alzheimers sykdom}

og demens med lewylegemer

Det var ti artikler med til sammen 1172 pasienter der man hadde sett på markørenes evne til å skille mellom pasienter med Alz-

Tabell 1 Oversikt over tre spinalvæskemarkører (5)

\begin{tabular}{lll} 
Markør & Patologisk substrat & Endring ved Alzheimers sykdom \\
Abeta42 & Betaamyloidpeptider, senile plakk & Redusert \\
\hline Tau & Nevrofibrillære floker, nevrontap & $\emptyset k t$ \\
P-tau & $\begin{array}{l}\text { Hyperfosforylering av tau, nevrofibrillære } \\
\text { floker, nevrontap }\end{array}$ & $\emptyset \mathrm{kt}$ \\
\end{tabular}

Tabell 2 Median sensitivitet og spesifisitet inkludert spredning for ulike spinalvæskebiomarkører

\begin{tabular}{|c|c|c|c|c|c|c|c|c|c|}
\hline \multirow[b]{2}{*}{ Markør } & \multicolumn{3}{|c|}{$\begin{array}{l}\text { Alzheimers sykdom } \\
\text { versus vaskulær demens }\end{array}$} & \multicolumn{3}{|c|}{$\begin{array}{l}\text { Alzheimers sykdom } \\
\text { versus demens med lewylegemer }\end{array}$} & \multicolumn{3}{|c|}{$\begin{array}{l}\text { Alzheimers sykdom } \\
\text { versus frontotemporallappsdemens }\end{array}$} \\
\hline & $\begin{array}{l}\text { Antall } \\
\text { artikler }\end{array}$ & $\begin{array}{l}\text { Sensitivitet, } \\
\% \text { (spredning) }\end{array}$ & $\begin{array}{l}\text { Spesifisitet, } \\
\% \text { (spredning) }\end{array}$ & $\begin{array}{l}\text { Antall } \\
\text { artikler }\end{array}$ & $\begin{array}{l}\text { Sensitivitet, } \\
\% \text { (spredning) }\end{array}$ & $\begin{array}{l}\text { Spesifisitet, } \\
\% \text { (spredning) }\end{array}$ & $\begin{array}{l}\text { Antall } \\
\text { artikler }\end{array}$ & $\begin{array}{l}\text { Sensitivitet, } \\
\% \text { (spredning) }\end{array}$ & $\begin{array}{l}\text { Spesifisitet, } \\
\% \text { (spredning) }\end{array}$ \\
\hline Abeta42 & 3 & 82 (77-87) & $67(62-80)$ & 2 & $69(48-89)$ & $58(21-94)$ & 4 & 75 (37-91) & 78 (59-92) \\
\hline Tau & 7 & $94(79-100)$ & $73(14-100)$ & 4 & 81 (72-94) & $82(53-92)$ & 7 & $74(58-88)$ & $82(68-92)$ \\
\hline P-tau 181 & 3 & $78(78-80)$ & $92(63-96)$ & 5 & $80(68-85)$ & $69(61-85)$ & 6 & $85(44-91)$ & $82(79-100)$ \\
\hline
\end{tabular}

heimers sykdom og pasienter med demens med lewylegemer $(13,15,20,22-28)$ (fig 3, e-tab 4). Median kvalitetsskår var 3 (spredning 2-5). Det var ikke statistisk signifikant forskjell mellom abeta42-nivået hos dem med Alzheimers sykdom og hos dem med demens med lewylegemer i noen av de seks studiene der man hadde sett på dette $(13,22-26)$. Sensitivitet og spesifisitet var rapportert for abeta42 i to studier (fig 3, tab 2, e-tab 4) $(24,27)$.

I én av de sju studiene av tau fant man ikke statistisk signifikant forskjell mellom gruppene (22), mens det i de andre seks var høyere taukonsentrasjon hos pasienter med Alzheimers sykdom $(13,15,24-27)$. Sensitivitet og spesifisitet var rapportert for tau i fire studier (fig 3, tab 2, e-tab 4) $(15,24,25,27)$.

P-tau 181 var undersøkt i fem studier. I én fant man like verdier hos pasientene med Alzheimers sykdom og pasientene med demens med lewylegemer (22), mens det i de andre fire studiene var høyere verdier hos dem med Alzheimers sykdom (23, 24, 26, 28). I alle de fem studiene var sensitivitet og spesifisitet for p-tau 181 undersøkt $(20,23$, $24,26,28$ ) (fig 3 , tab 2, e-tab 4).

I seks av studiene hadde man sett på ulike kombinasjoner av markørene, og sensitivitet mellom $56 \%$ og $94 \%$ og spesifisitet mellom $67 \%$ og $94 \%$ ble rapportert $(13,22-25,27)$.

\section{Alzheimers sykdom}

og frontotemporallappsdemens

Det fantes totalt ti studier, med til sammen 838 pasienter, der man hadde sett på nytten av markørene ved differensialdiagnostikk mellom Alzheimers sykdom og frontotemporallappsdemens $(15,20,21,24,28-35)$ (fig 4, e-tab 5). Median kvalitetsskår var 3 (spredning 2-4).

I fem av seks studier der abeta42-konsentrasjon var rapportert, var denne statistisk signifikant høyere hos pasienter med frontotemporallappsdemens enn hos pasienter med Alzheimers sykdom (24, 29-32). I én studie var det ikke noen forskjell (33). I fire studier hadde man sett på sensitivitet og spesifisitet for abeta42s evne til å skille mellom gruppene $(24,29-31)$ (fig 4, tab 2, e-tab 5).

Taukonsentrasjonen var målt $i$ åtte studier. Det ble funnet statistisk signifikant høyere konsentrasjoner hos pasienter med Alzheimers sykdom i alle studiene $(15,24$, 29-34). Sensitivitet og spesifisitet var rap- 
portert i sju studier $(15,24,29-32,34)$ (fig 4, tab 2, e-tab 5).

Når det gjaldt p-tau, var det én studie der det ikke var statistisk signifikant forskjell mellom p-tau 181-nivå hos pasienter med Alzheimers sykdom og hos pasienter med frontotemporallappsdemens (29) - i fem andre studier hvor p-tau 181 var undersøkt, fant man høyere konsentrasjoner hos dem med Alzheimers sykdom enn hos dem med frontotemporallappsdemens $(24,28,31,33,34)$. Sensitivitet og spesifisitet for evnen til p-tau 181 til å skille gruppene, var rapportert i fem studier $(20,24$, $28,31,34$ ) (fig 4, tab 2, e-tab 5).

Ulike kombinasjoner av markørene for å skille pasienter med Alzheimers sykdom og pasienter med frontotemporallappsdemens var undersøkt i fem av studiene, i disse var det en sensitivitet på $72-86 \%$ og en spesifisitet på 80-97\% $(24,30-33)$.

\section{Diskusjon}

Studiene tyder på at konsentrasjonen av abeta42 i spinalvæske er lavere hos pasienter med Alzheimers sykdom enn hos pasienter med vaskulær demens og frontotemporallappsdemens, mens tau- og p-tauverdien er høyere hos dem med Alzheimers sykdom enn hos dem med vaskulær demens, frontotemporallappsdemens og demens med lewylegemer. Det er stor spredning studiene imellom når det gjelder sensitivitet og spesifisitet for markørenes evne til å skille Alzheimers sykdom fra andre demensformer. Resultatene er ikke entydige - ut fra dette materialet kan man foreløpig ikke konkludere med at noen av markørene oppfyller kriteriene til en god biomarkør (4).

Ulike kombinasjoner av markørene har vært undersøkt, de fleste kombinasjonene kun i én eller to studier. Det er nødvendig med flere undersøkelser for å vurdere nytten av dette.

\section{Svakheter}

Flere begrensninger gjør nytten av markørene vanskelig å vurdere. Én viktig begrensning er at det er så få studier med obduksjonsverifiserte diagnoser. Klinisk diagnostikk er usikker, og kun i tre studier var diagnostikken i noen utstrekning basert på obduksjon (12, 20, 32). I tillegg har det i de fleste studiene vært små og selekterte materialer, og det finnes få multisenterstudier med denne problemstillingen. En annen svakhet er at flere av studiene, inkludert enkelte av dem med høy sensitivitet og spesifisitet, var basert på pasienter med mer alvorlig grad av demens, mens det er mest behov for biomarkører for å skille demensformene tidlig i sykdommen.

I noen studier er alle med Alzheimers sykdom med vaskulære lesjoner på CT og MR blitt ekskludert, $i$ andre undersøkelser er disse blitt klassifisert $\mathrm{i}$ en egen gruppe eller som pasienter med Alzheimers sykdom. Hvordan man skal diagnostisere pasienter med blandet demens er en utfordring. Dette gjelder særlig for demens med lewylegemer, hvor graden av samtidige tegn på Alzheimers sykdom va-

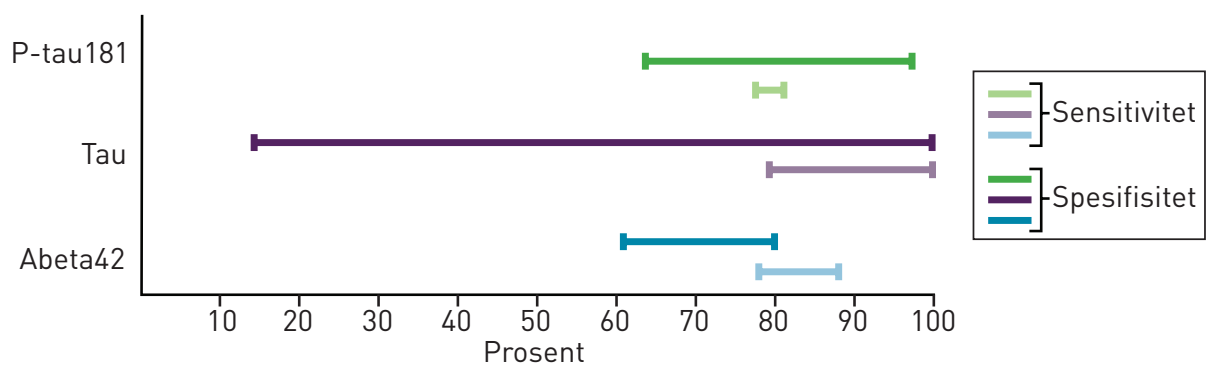

Figur 2 Spredningen i rapportert sensitivitet og spesifisitet for ulike biomarkørers evne til å skille Alzheimers sykdom fra vaskulær demens (9, 11, 14-20)

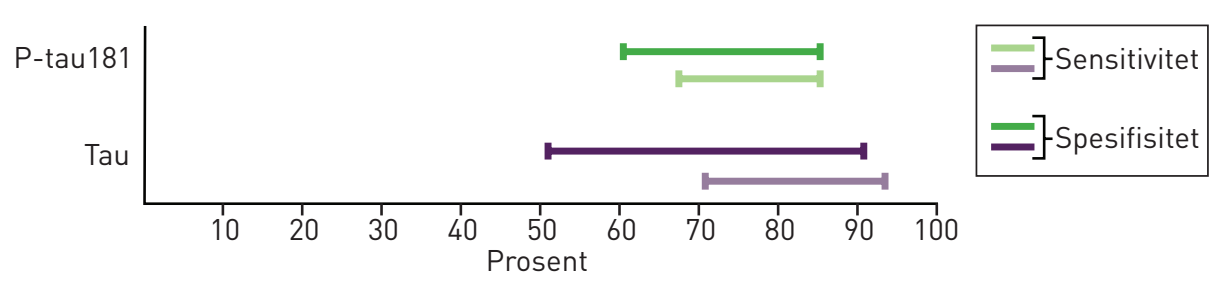

Figur 3 Spredningen i rapportert sensitivitet og spesifisitet for ulike biomarkørers evne til å skille Alzheimers sykdom fra demens med lewylegemer (15, 20, 23-28). Abeta42 er ikke inkludert fordi det i kun to artikler var rapportert sensitivitet og spesifisitet for denne markøren

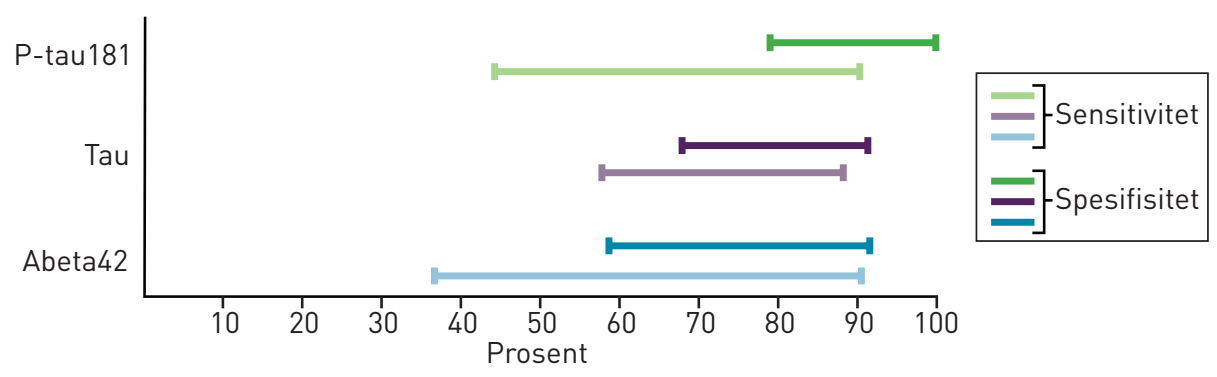

Figur 4 Spredningen i rapportert sensitivitet og spesifisitet for ulike biomarkørers evne til å skille Alzheimers sykdom fra frontotemporallappsdemens $(15,20,24,28-32,34)$

rierer sterkt, noe som sannsynligvis vil påvirke spinalvæskeverdiene av de tre markørene.

I studiene er det blitt brukt ulike metoder for å måle markørene, disse samsvarer i varierende grad (9). Men også for den metoden som er brukt i flest studier, Innotest ELISA fra Innogenetics, er det til dels stor variasjon i resultatene ulike studier imellom. Slik variasjon ser ut til å være spesielt stor for måling av abeta42 (6). For å kunne vurdere nytten av å bruke markørene klinisk er det nødvendig å standardisere analysene laboratoriene imellom og - ikke minst - sikre god preanalytisk prøvehåndtering. Det er vist at abeta42 adherer til overflater av glass og polystyren, derfor bør det brukes utstyr av polypropylen (36). Likevel er det i flere av de inkluderte studiene ikke opplyst hvilket utstyr som er brukt.

De fleste studiene har vært eksplorative, den forstand at man har valgt en grenseverdi (cut-off) for markørene som ga maksimal sensitivitet og spesifisitet $i$ hver enkelt studie. Dette vanskeliggjør tolking og sammenlikning av resultatene. Det er behov for studier der man undersøker sensitivitet og spesifisitet ut fra en a priori-bestemt grenseverdi.
En ideell biomarkør er lite invasiv. Det er oftere bivirkninger etter spinalpunksjon enn etter for eksempel venepunksjon, men det er data som tyder på at det er få tilfeller av postspinal hodepine hos demente. Blennow og medarbeidere registrerte komplikasjoner hos 395 demente pasienter som var blitt spinalpunktert. Kun $2 \%$ fikk hodepine, og den var i alle tilfellene mild (37). Svært sjelden inntreffer det alvorlige komplikasjoner. Det er likevel behov for å forbedre analysemetodene før spinalvæske kan anbefales brukt i differensieringen av ulike demensdiagnoser. Flere nye internasjonale retningslinjer anbefaler spinalvæskemarkørene som diagnostisk hjelpemiddel for å stille diagnosen Alzheimers sykdom hos personer med begynnende mental svekkelse $(38,39)$. Foreløpig er det imidlertid ikke gode nok holdepunkter for å hevde at spinalvæskemarkørene alene kan bidra til å skille Alzheimers sykdom fra andre demenstyper.

Utvidet metodebeskrivelse, e-tab 3, e-tab 4 og e-tab 5 finnes kun i Tidsskriftets nettutgave. 


\section{Ragnhild Eide Skogseth (f. 1982)}

er cand.med. Hun har gått forskerlinjen og er for tiden turnuslege ved Voss sykehus.

Ingen oppgitte interessekonflikter.

\section{Tormod Fladby (f. 1959)}

er professor i nevrologi, avdelingssjef ved nevroklinikken ved Akershus universitetssykehus, som bl.a. innbefatter en hukommelsesklinikk. Han leder en forskningsgruppe som fokuserer på etiologi, tidlig diagnostikk og utprøvende behandling for kognitiv svikt og demens. Ingen oppgitte interessekonflikter.

\section{Ezra Mulugeta (f. 1964)}

har doktorgrad fra Karolinska Institutet og er tilknyttet King's College i London, der han har vært postdoktor. Han har jobbet ved Senter for nevro- og alderspsykiatrisk forskning ved Stavanger universitetssjukehus og er for tiden ansatt ved undersøkelseslaboratoriet for legemiddelkvalitet i Uppsala.

Ingen oppgitte interessekonflikter.

\section{Dag Aarsland (f. 1959)}

er dr.med. og spesialist i psykiatri. Han er forskningsleder og seksjonsoverlege ved Regionalt senter for eldremedisin og samhandling (SESAM), Stavanger universitetssjukehus, og professor i demensforsknings ved Centrum för Alzheimerforskning, Karolinska Institutet. I tillegg er han tilknyttet Universitetet i Oslo og Akershus universitetssykehus. Ingen oppgitte interessekonflikter.

\section{Litteratur}

1. Skogseth RE. Stikk for bedre diagnostikk - spinalvæskebiomarkører ved demenssykdommer. Bergen: Universitetet i Bergen, 2010.

2. Knopman DS, DeKosky ST, Cummings JL et al. Practice parameter: diagnosis of dementia (an evidence-based review). Neurology 2001; 56 : $1143-53$.

3. The Ronald and Nancy Reagan Research Institute of the Alzheimer's Association and the National Institute on Aging Working Group. Consensus report of the Working Group on: «Molecular and Biochemical Markers of Alzheimer's Disease». Neurobiol Aging 1998; 19: 109-16.

4. Andreasen N, Blennow K. CSF biomarkers for mild cognitive impairment and early Alzheimer's disease Clin Neurol Neurosurg 2005: 107: 165-73.

5. Mattsson N, Zetterberg H, Hansson $\mathrm{O}$ et al. CSF biomarkers and incipient Alzheimer disease in patients with mild cognitive impairment. JAMA 2009: 302: 385-93.

6. Frankfort SV, Tulner LR, van Campen JP et al. Amyloid beta protein and tau in cerebrospinal fluid and plasma as biomarkers for dementia: a review of recent literature. Curr Clin Pharmacol 2008: 3: $123-31$

7. Aarsland D, Zaccai J, Brayne C. A systematic review of prevalence studies of dementia in Par kinson's disease. Mov Disord 2005; 20: 1255-63.

8 . de Jong D, Jansen RW, Kremer BP et al. Cerebrospinal fluid amyloid beta42/phosphorylated tau ratio discriminates between Alzheimer's disease and vascular dementia. J Gerontol A Biol Sci Med Sci 2006; 61: 755-8.

9. Reijn TS, Rikkert MO, van Geel WJ et al. Diagnostic accuracy of ELISA and xMAP technology for analysis of amyloid beta(42) and tau proteins. Clin Chem 2007; 53: 859-65.

10. Bibl M, Esselmann H, Mollenhauer B et al. Bloodbased neurochemical diagnosis of vascular dementia: a pilot study. J Neurochem 2007; 103: 467-74
11. Stefani A, Bernardini S, Panella M et al. AD with subcortical white matter lesions and vascular dementia: CSF markers for differential diagnosis. J Neurol Sci 2005; 237: 83-8.

12. Le Bastard N, Van Buggenhout M, De Leenheir E et al. LOW specificity limits the use of the cerebrospinal fluid AB1 -42/P-TAU181P ratio to discriminate Alzheimer's disease from vascular dementia. J Gerontol A Biol Sci Med Sci 2007; 62: 923 -4. author reply $924-5$

13. Andreasen N, Minthon L, Davidsson P et al. Evaluation of CSF-tau and CSF-Abeta42 as diagnostic markers for Alzheimer disease in clinical practice. Arch Neurol 2001: 58: 373-9.

14. Kapaki E, Paraskevas GP, Zalonis I et al. CSF tau protein and beta-amyloid (1-42) in Alzheimer's disease diagnosis: discrimination from normal ageing and other dementias in the Greek population. Eur J Neurol 2003: 10: 119-28.

15. Buerger K, Zinkowski R, Teipel SJ et al. Differential diagnosis of Alzheimer disease with cerebrospinal fluid levels of tau protein phosphorylated at threonine 231. Arch Neurol 2002; 59: 1267-72.

16. Boban M, Grbic K, Mladinov M et al. Cerebrospinal fluid markers in differential diagnosis of Alzheimer's disease and vascular dementia. Coll Antropol 2008; 32 (suppl 1): 31-6

17. Andreasen $N$, Vanmechelen $E$, Van de Voorde A et al. Cerebrospinal fluid tau protein as a biochemical marker for Alzheimer's disease: a communit based follow up study. J Neurol Neurosurg Psychiatry 1998; 64: 298-305

18. Paraskevas GP, Kapaki E, Liappas I et al. The diagnostic value of cerebrospinal fluid tau protein in dementing and nondementing neuropsychiatric disorders. J Geriatr Psychiatry Neurol 2005; 18 : $163-73$

19. Hu YY, He SS, Wang $X$ et al. Levels of nonphosphorylated and phosphorylated tau in cerebrospinal fluid of Alzheimer's disease patients : an ultrasensitive bienzyme-substrate-recycle enzymelinked immunosorbent assay. Am J Pathol 2002; 160: $1269-78$

20. Koopman K, Le Bastard N, Martin JJ et al. Improved discrimination of autopsy-confirmed Alzheimer's disease (AD) from non-AD dementias using CSF P-tau(181P). Neurochem Int 2009: 55: 214-8.

21. McKhann G, Drachman D, Folstein M et al. Clinical diagnosis of Alzheimer's disease: report of the NINCDS-ADRDA Work Group under the auspices of Department of Health and Human Services Task Force on Alzheimer's Disease. Neurology 1984; 34 : $939-44$

22. Nielsen HM, Minthon L, Londos E et al. Plasma and CSF serpins in Alzheimer disease and dementia with Lewy bodies. Neurology 2007; 69: 1569-79.

23. Wada-Isoe K, Kitayama M, Nakaso K et al. Diagnostic markers for diagnosing dementia with Lewy bodies: CSF and MIBG cardiac scintigraphy study. J Neurol Sci 2007: 260: 33-7.

24. de Jong D, Jansen RW, Pijnenburg YA et al. CSF neurofilament proteins in the differential diagnosis of dementia. J Neurol Neurosurg Psychiatry 2007 78: $936-8$.

25. Gómez-Tortosa E, Gonzalo I, Fanjul S et al. Cerebrospinal fluid markers in dementia with lewy bodies compared with Alzheimer disease. Arch Neurol 2003; 60: 1218-22.

26. Vanderstichele $\mathrm{H}$, De Vreese K, Blennow K et al. Analytical performance and clinical utility of the INNOTEST PHOSPHO-TAU181P assay for discrimination between Alzheimer's disease and dementia with Lewy bodies. Clin Chem Lab Med 2006: 44: 1472-80.

27. Bibl M, Mollenhauer B, Esselmann $\mathrm{H}$ et al. CSF diagnosis of Alzheimer's disease and dementia with Lewy bodies. J Neural Transm 2006; 113 $1771-8$

28. Hampel H, Buerger K, Zinkowski R et al. Measurement of phosphorylated tau epitopes in the differential diagnosis of Alzheimer disease: a comparative cerebrospinal fluid study. Arch Gen Psychiatry 2004: 61: 95-102

29. Grossman M. Farmer J, Leight S et al. Cerebrospinal fluid profile in frontotemporal dementia and Alzheimer's disease. Ann Neurol 2005; 57: 721 -9.

30. Riemenschneider M, Wagenpfeil S, Diehl J et al. Tau and Abeta42 protein in CSF of patients with frontotemporal degeneration. Neurology 2002; 58 1622-8

31. Schoonenboom NS, Pijnenburg YA, Mulder $\mathrm{C}$ et al.
Amyloid beta(1-42) and phosphorylated tau in CSF as markers for early-onset Alzheimer disease. Neurology 2004; 62: $1580-4$.

32. Bian H, Van Swieten JC, Leight S et al. CSF biomarkers in frontotemporal lobar degeneration with known pathology. Neurology 2008; 70 (19, Pt 2): 1827-35

33. Blasko I, Lederer W, Oberbauer $\mathrm{H}$ et al. Measurement of thirteen biological markers in CSF of patients with Alzheimer's disease and other dementias. Dement Geriatr Cogn Disord 2006; 21: $9-15$.

34. Sjögren M, Davidsson P, Tullberg M et al. Both total and phosphorylated tau are increased in Alzheimer's disease. J Neurol Neurosurg Psychiatry 2001; 70: 624-30

35. Skovronsky DM, Lee VMY, Praticò D. Amyloid precursor protein and amyloid beta peptide in human platelets. Role of cyclooxygenase and protein kinase C. J Biol Chem 2001; 276: 17036-43.

36. Andreasen N, Hesse C, Davidsson P et al. Cerebrospinal fluid beta-amyloid(1-42) in Alzheimer disease: differences between early- and late-onset Alzheimer disease and stability during the course of disease. Arch Neurol 1999; 56: 673-80.

37. Blennow K, Wallin A, Häger O. Low frequency of post-lumbar puncture headache in demented patients. Acta Neurol Scand 1993; 88: 221-3.

38. Dubois B, Feldman HH, Jacova $C$ et al. Research criteria for the diagnosis of Alzheimer's disease: revising the NINCDS-ADRDA criteria. Lancet Neurol 2007: 6: 734-46.

39. Albert MS, DeKosky ST, Dickson D et al. The diagnosis of mild cognitive impairment due to Alzheimer's disease: recommendations from the National Institute on Aging-Alzheimer's Association workgroups on diagnostic guidelines for Alzheimer's disease. Alzheimers Dement 2011: 7: 270-9.

Mottatt 5.2. 2010, første revisjon innsendt 9.8 . 2010, godkjent 7.7. 2011. Medisinsk redaktør Siri Lunde. 